\title{
Волоконные лазеры с распределенной обратной связью на основе регулярных и случайных структур показателя преломления
}

\author{
С.А. Бабин ${ }^{1,2}$, М.И.Скворцов ${ }^{1}$, А.А. Воль $\phi^{1}$, А.В. Достовалов ${ }^{1}$, С.Р. Абдуллина ${ }^{1}$, А.А. Власов ${ }^{1}$ \\ ${ }^{1}$ Институт автоматики и электрометрии СО РАН, Новосибирск, 630090, Коптюга, 1 \\ ${ }^{2}$ Новосибирский государственный университет, Новосибирск, 630090, Пирогова, 1 \\ тел: +7 (383) 330-79-69, факс:+7 (383) 330-8878, эл. nочта: babin@iae.nsk.su
}

DOI 10.34077/RCSP2021-19

Резонатор лазера с распределенной обратной связью (РОС) обычно представляет собой периодическую структуру, сформированную непосредственно в активной среде. В волоконных РОСлазерах в активном волокне формируется брэгговская решётка показателя преломления (ПП) длиной 5-10 см с фазовым сдвигом на пол-периода в центре структуры, что обеспечивает стабильный одночастотный режим генерации. Волоконная брэгговская решётка (ВБР) может также иметь много фазовых сдвигов, наведенных при записи, в т.ч. случайных [1], в последнем случае говорят о случайном РОС (СРОС) лазере. В километровых волокнах слабая СРОС на естественных неоднородностях показателя преломления, определяющих рэлеевское рассеяние, может быть достаточной для генерации, если интегральное усиление велико - при этом в пассивных волокнах для усиления используется эффект ВКР [2]. Увеличение рэлеевского рассеяния в пассивных волокнах за счет формирования искусственных случайных структур ПП позволяет уменьшить длину таких СРОСлазеров до сотен метров [3].

В докладе дан обзор последних достижений в области волоконных РОС и СРОС лазеров, а также их гибридных вариантов, включающих как регулярные, так и случайные структуры ПП. Новые возможности формирования таких структур в активных и пассивных волокнах даёт технология фемтосекундной (фс) поточечной лазерной модификации, применимая не только в одномодовых, но и в многомодовых/многосердцевинных волоконных световодах [4].

В частности, технология поточечной фс модификации позволила создать РОС-лазер рекордно короткой длины (5,3 мм) в композитном эрбиевом световоде [5], причем его характеристики не уступают характеристикам обычных волоконных РОС-лазеров с длиной резонатора на порядок больше, в частности, измеренная ширина линии составила единицы кГц при мощности 0,5 мВт. С помощью фс технологии в пассивном волокне длиной 5-10 см был сформирован искусственный рэлеевский отражатель - он имеет малые потери и в комбинации с эрбиевым POС-лазером такой гибридный лазер с регулярной и случайной РОС позволяет на порядок уменьшить ширину линии одночастотной генерации (с $\sim 1$ до $\sim 0,1$ кГц) в телекоммуникационном диапазоне спектра $(\sim 1,55$ мкм). Искусственный рэлеевский отражатель также использовался совместно с обычной ВБР. В таком полуоткрытом резонаторе с усиливающим композитным эрбиевым волокном длиной 35 см получена одночастотная $(<0,5$ кГц) генерация мощностью $1,5 \mathrm{mBT}$, а при увеличении мощности до $12 \mathrm{mBT}$ наблюдается уширение линии генерация до 100 МГц. При этом продемонстрирована возможность перестройки частоты в телекоммуникационном диапазоне за счет сжатия ВБР.

Массив ВБР со случайной относительной фазой и амплитудой, записанный в 7 м пассивного одномодового волокна, сохраняющего поляризацию, позволяет получить одночастотную случайную ВКР-генерацию мощностью $\sim 10$ мВт, увеличение мощности накачки позволяет получить поляризованную узкополосную генерацию (<80 пм) мощностью $>6$ ВТ@ 1,1 мкм с возможностью перестройки внутри линии усиления ВКР [6]. Кроме того, исследована случайная ВКР-генерация с полуоткрытым резонатором из двух ВБР с одной стороны и рэлеевской СРОС в 500 м 2-сердцевинного волокна [7], а также в 7-сердцевинном волокне с массивами из 6 ВБР (в разных сердцевинах) с каждой стороны - продемонстрировано сужение линии за счет случайного продольного сдвига ВБР в массиве.

Рассмотрены возможности практических применений разработанных лазеров.

Работа выполнена при финансовой поддержке гранта РНФ (21-72-30024).

\section{Лumepamypa}

[1] M. Gagné, R. Kashyap // Opt. Express 17 (21), 19067-19074 (2009).

[2] S.K. Turitsyn, S.A. Babin, D.V. Churkin, et al. // Phys. Reports 542, 133-193 (2014).

[3] X. Wang, D. Chen, H. Li, et al. // Applied Optics 57 (2), 258-262 (2018).

[4] A. V. Dostovalov, A. A. Wolf, M. I. Skvortsov, et al. // Opt. Fib. Technol. 52, 101988 (2019).

[5] M. I. Skvortsov, A. A. Wolf, A. A. Vlasov, et al. // Sci. Reports 10, 14487 (2020).

[6] S. R. Abdullina, M. I. Skvortsov, A. A. Vlasov, et al. // Las. Phys. Lett. 16, 105001 (2019).

[7] M. I. Skvortsov, S. R. Abdullina, A. A. Wolf, et al. Opt. Lett. 44, 295-298 (2019). 